

\title{
THE EFFECTS OF MACROECONOMIC VARIABLES ON THE MARKET CAPITALISATION OF LISTED COMPANIES IN KENYA
}

\section{(A case of Nairobi Security Exchange)}

\author{
1"Mark Mjomba, \\ ${ }^{1 *}$ Post graduate student, \\ Catholic University of Eastern Africa \\ *Corresponding Author's Email: maq55@live.com
}

Purpose: This study aims to find out the effects of macroeconomic variables on market capitalization in Kenya.

Methodology:The study adopted a descriptive research design. The target population was all the employees of Nairobi Securities Exchange. The study used a purposive sampling method to access data from the population of study. A random sampling technique was used to select a sample size of 96 respondents. Secondary data on these variables ranging from 1980 to 2014 was analysed using inferential statistics. Time series analysis and regression model were employed in the analysis.

Results:The findings of study indicated that exchange rates had a positive and significant effect on market capitalisation of listed companies, the findings also shows that exchange rates had a fluctuating pattern during the period of study. Further the findings showed that interest rates and public debt had a negative significant effect on market capitalisation. An increase in domestic interest rates had corresponding negative impact on capital market. Further the findings showed that inflation rates had a negative effect on market capitalisation but the effect was less significant compared to interest rates, exchange rates and public debt. These findings do not primarily conclude that inflation rates, interest rates, exchange rates and public debt are the chief determinants of market capitalisation since market capitalisation is also affected by other variables not included in this study.

Policy recommendation: The study therefore recommends that the Securities and Exchange Commission of Kenya should consider the trends in the variables under the study in policy formulation to ensure the development of a modern and efficient capital market sector based on sound policies that provide momentum for high and steady capital market.

Keywords: public debt,exchange rates, inflation, inflation 


\section{1: INTRODUCTION}

Effects of micro and macroeconomic variables were extremely significant for theresearchers in olden times. Researchers, economists and students have attempted a lot for several years for discovering the relationship between macro-economic factors and stock market. Many factors which leads to change in the stock market. These purpose, researchers have applied different models in the fascination to discover the relationship between macro-economic variables and stock market (Pan et al., 2007). Therefore, the importance of the study increases because of the search to discover the effect of macroeconomic factors on the stock market. Dealing of the stocks takes place in the stock market.

Capital market plays very important rule in the development of an economy and acts like intermediary. In the secondary stock market, Securities traded. In the stock market, security is primarily the conversion of funds. Stock markets provide investment opportunity. Change in stock exchange index causes disturbance in the macroeconomic factors (Adam at al., 2008). Stock market by liquidity and risks sharing, accelerate the economic growth. The increase and decrease in stock prices is an understandable phenomenon of economies among the investors, corporation, policy makers and researcher. Market forces i.e. demand and supply, determined the stock prices, and if supply equal to demand of seller, at that position stock price is fixed.

\subsection{Problem Statement}

The stock market has become an essential market playing a vital role in economic prosperity thus fostering capital formation and sustaining economic growth. Stock markets are more than a place to trade securities; they operate as a facilitator between savers and users of capital by means of pooling of funds, sharing risk, and transferring wealth. Stock markets are essential for economic growth as they facilitate the flow of resources to the most productive investment opportunities in other words; they help in terms of efficient allocation of credit in the economy. Demirguc-Kunt and Levine (1996), Singh (1997) and Levine and Zervos (1998) find that stock market growth plays an important role in predicating future economic growth in situations where the stock markets are active. The arguments of Demirguc-Kunt et al. (1996) indicate that economies without well-functioning stock markets may suffer from three types of imperfections: first, opportunities for risk diversification are limited forinvestors and entrepreneurs, second, firms are unable to optimally structure their financing packages and third, countries without well functioning markets lack information about the prospects of firms whose shares are traded, thereby restricting the promotion of investment and its ef efficiency. The proponents of stock markets emphasize the importance of having a developed stock market in enhancing the efficiency of investment. Recognizing the importance of stock market on economic growth, prudential authorities such as World Bank, IMF and ADB undertook stock market development programs for emerging markets in developing countries during 80s and 90s and found that, the emerging stock markets have experienced considerable development since the early 1990s. In light of the above presentation, the importance of Nairobi stock exchange to the entire East African community.

The stock markets in emerging markets have seen considerable development since the early 1990s. The market capitalization of emerging market countries has more than doubled over the 
past decade growing from less than $\$ 2$ trillion in 1995 to about $\$ 5$ trillion in 2005. As a percentage of world market capitalization, emerging markets are now more than 12 percent and steadily growing (Standard and Poor, 2005). The rapid development of stock in emerging market does not mean that even the most advanced emerging stock markets are mature. In most stock markets, trading occurs in only a few stocks, which account for a considerable part of the total market capitalization. Beyond these actively traded shares, there are serious informational and disclosure deficiencies for other stocks. There are serious weaknesses in the transparency of transactions on these markets. The less developed of the stock markets suffer from a far wider range of such deficits. Compared with the highly organized and properly regulated stock market activity in the US and the UK, most emerging markets do not have such a well-functioning market. Not only is there inadequate government regulation, private information gathering and dissemination firms as found in more developed stock markets are inadequate. Moreover, young firms in emerging stock markets do not have a long enough track record to form a reputation. As a result, one expects share prices in emerging markets to be arbitrary and volatile (Tirole, 1991)

\subsection{Objectives of the study}

1. To assess the effect of public debt on the market capitalisation.

2. To establish the effect of exchange rates on the market capitalisation.

3. To determine the effect of inflation on the market capitalisation.

4. To find out market capitalisation the effect of interest rates on the market capitalisation.

\section{4: Conceptual framework}

\begin{tabular}{|l|l|}
\hline Macro-economic variables \\
- Interest rates \\
- Exchange rate \\
- Inflation \\
- Public debt
\end{tabular}

\section{Figure 1:Conceptual Framework}

Source: Researcher's own model (2013)

\section{0: METHODOLOGY}

The study adopted a descriptive research design. The target population was all the employees of Nairobi Securities Exchange. The study used a purposive sampling method to access data from the population of study. A random sampling technique was used to select a sample size of 96 
International Journal of Finance And Accounting

ISSNxxxx-xxxx (Paper)ISSN 2518-4113 (Online)

Vol.2, Issue 4, No.4 pp 58 - 83, 2017

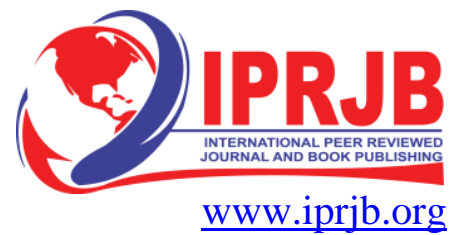

respondents. Secondary data on these variables ranging from 1980 to 2014 was analysed using inferential statistics. Time series analysis and regression model were employed in the analysis.

\subsection{RESULTS FINDINGS}

\subsection{Descriptive Statistics}

Results in table 1 indicate the descriptive statistics of Inflation Rate, public debt, exchange Rates, Interest Rates and market capitalisation of listed companies. As indicated in the table below the Mean Inflation Rate for the period 1980 to 2014 was 12.78 with a standard deviation of 8.76 indicating moderate variability in Inflation Rate over time. The Minimum and Maximum values of Inflation Rate over the same period of time were 1.55 and 45.98 respectively. The Mean Interest Rate for the period 1980 to 2014 was 17.840 with a standard deviation of 7.228 indicating moderate variability in Interest Rate over time. The Minimum and Maximum values of Interest Rate over the same period of time were 8.1 and 36.24 respectively. The results further indicate that The Mean lag public debt for the period is 3.939 with a standard deviation of 2.35. This indicates a small variability in public debt. The minimum and maximum values of lag public debt are 0.875 and 10.49 respectively. As shown in the table below.

Table 1: $\quad$ Descriptive Statistics

- sum mktcapitalisation exchangerate inflationrates interestrates publicdebt

\begin{tabular}{r|rrrrr} 
Variable & Obs & Mean & Std. Dev. & Min & Max \\
\hline mktcapital n & 35 & 9.279628 & .5762583 & 8.656098 & 10.16999 \\
exchangerate & 35 & 51.8264 & 28.60605 & 7.420187 & 88.81077 \\
inflationr s & 35 & 12.78902 & 8.76734 & 1.554328 & 45.97888 \\
interestra s & 35 & 17.84057 & 7.228517 & 8.1 & 36.24 \\
publicdebt & 35 & 3.939845 & 2.356012 & .8752522 & 10.49005
\end{tabular}

\subsection{Trend Analysis}

This section presents the trend analysis of public debt, interest rates, inflation rates, exchange rates and market capitalisation. The trend analysis is conducted so as to help establish the movement of the variables under study and thus help in performing unit root analysis as the trend analysis graphically indicates the pattern of movement in the variables.

\subsubsection{Trend Analysis for Public Debt}

The Figure 5 indicates that has been significantly increasing since 1980 . The trend also shows a sharp increase between 1992-1995 where public hit it's highest. The trend shows from 1995 public debt has been reducing with the lowest recorded in 2010. This gradual decline in the 
public debt is mainly attributable to local generation of finances through taxation and

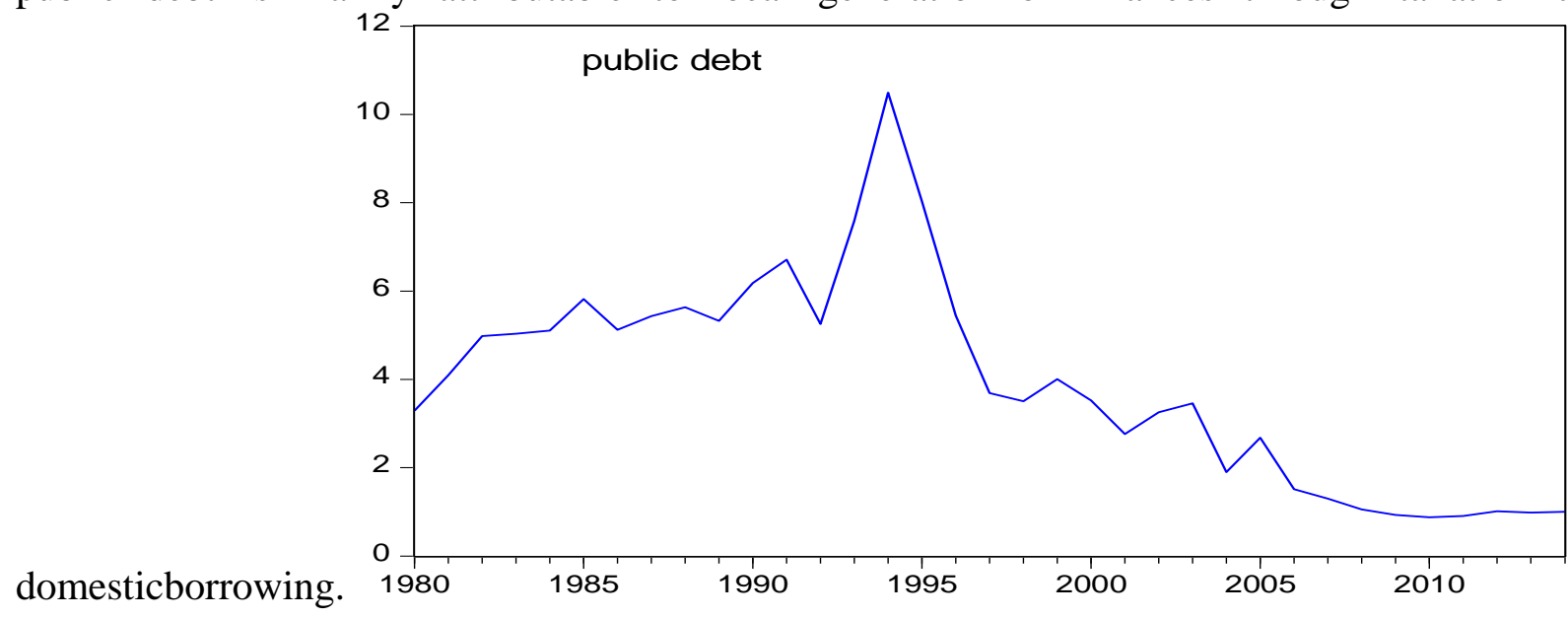

Figure 2: Yearly Trend Analysis of Public Debt

\subsubsection{Trend Analysis for exchange rate}

The Figure 5 indicates that has been significantly increasing since 1980. There has small reduction in exchange rates for instance in 1995 and 2006 but this reduction was not significant enough to affect the overall increase from 1980 to 2014

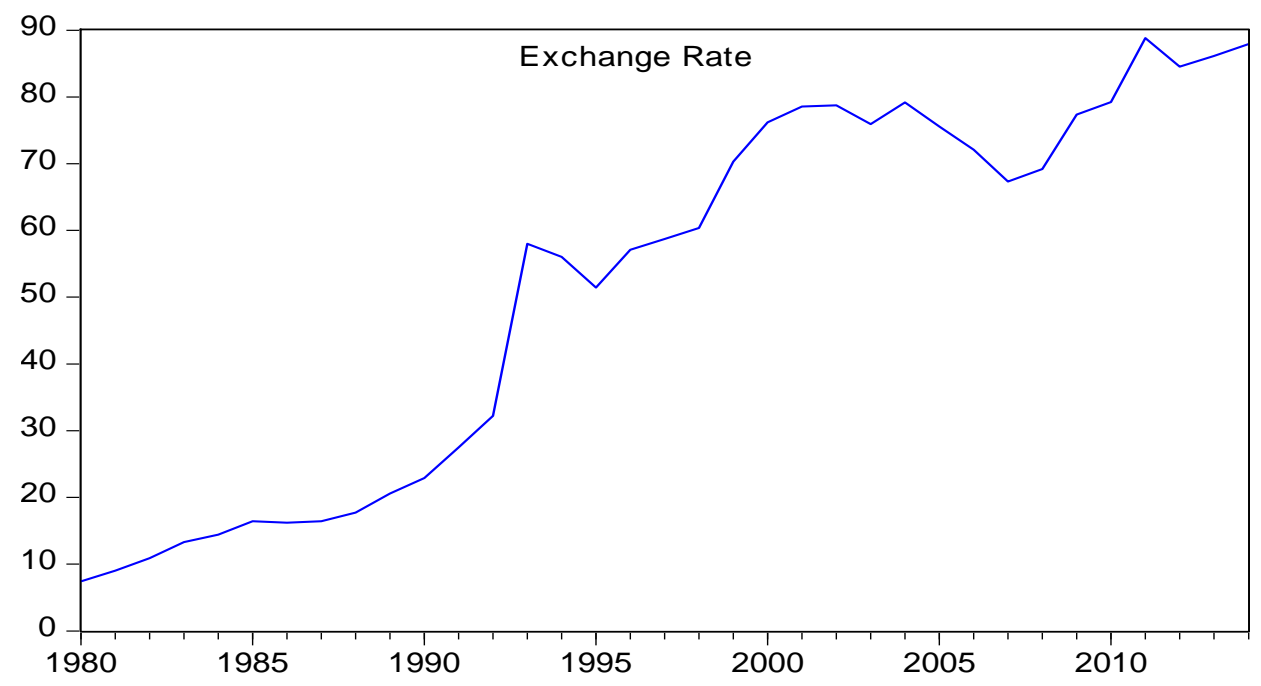

Figure 3: Yearly Trend for Exchange Rates

\subsubsection{Trend Analysis for inflation rate}

Figure 6 indicates that country had the highest inflation in 1982, 1993 and 2008 this inflation can be attributed to political events synonymous to these years. The results also indicates the country had the lowest inflation in 1985, 1995, 2002 and in 2010. The result also indicates fluctuating trends of inflation rates. Tightened monetary policy, together with an easing in global food and 
International Journal of Finance And Accounting

ISSNxxxx-xxxx (Paper)ISSN 2518-4113 (Online)

Vol.2, Issue 4, No.4 pp 58 - 83, 2017

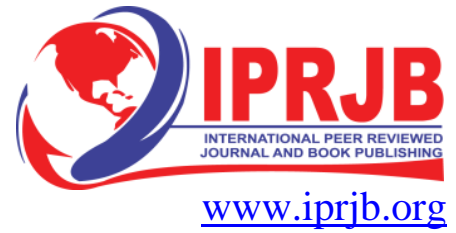

fuel prices, have brought inflation under control and stabilized the economy in 2012. The trend analysis for inflation is shown in the figure below.

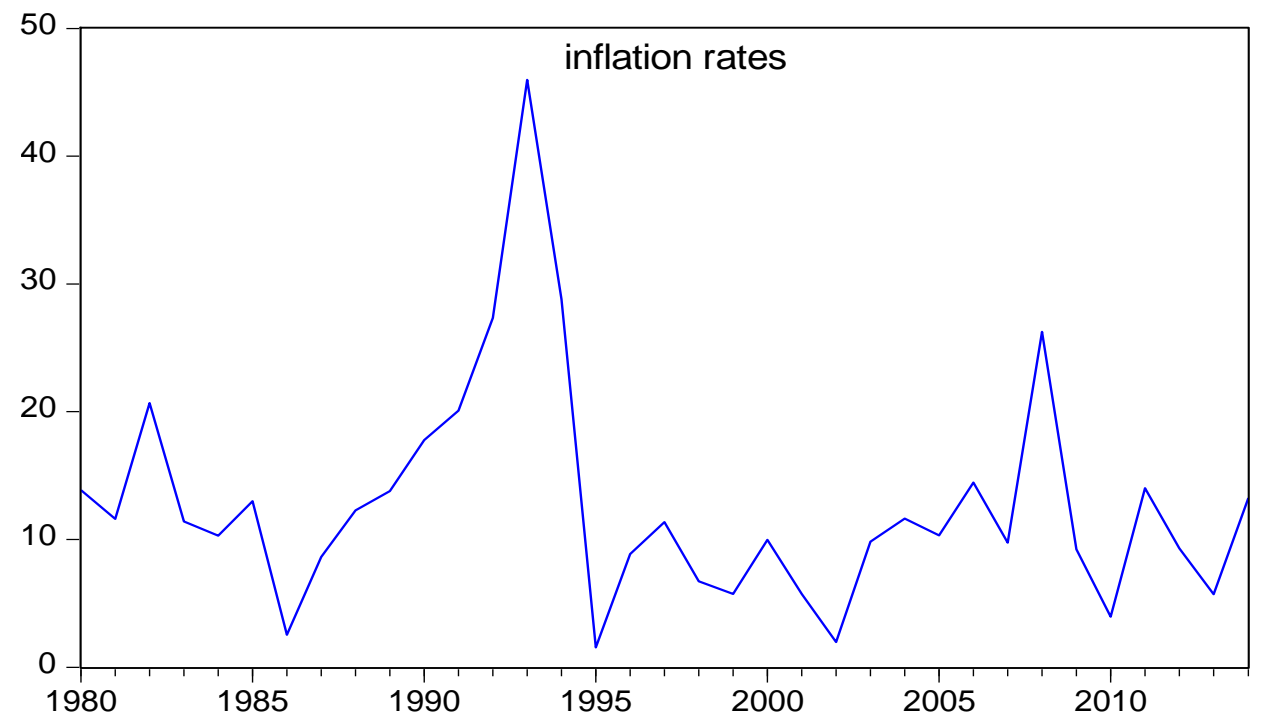

Figure 4.3: $\quad$ Yearly Trend for Inflation Rates

\subsubsection{Trend Analysis for Interest Rates}

Figure 7 shows that interest rates have been increasing from 1980 to 2004 followed by a decline from the year 2001 to 2004. This decline was associated with the loosening of monetary policies by the central bank. Between the year 2005 and 2011; interest rate rose gradually and reached its peak in the year 2012. The high interest rate in the year 2012 cooled the economy.

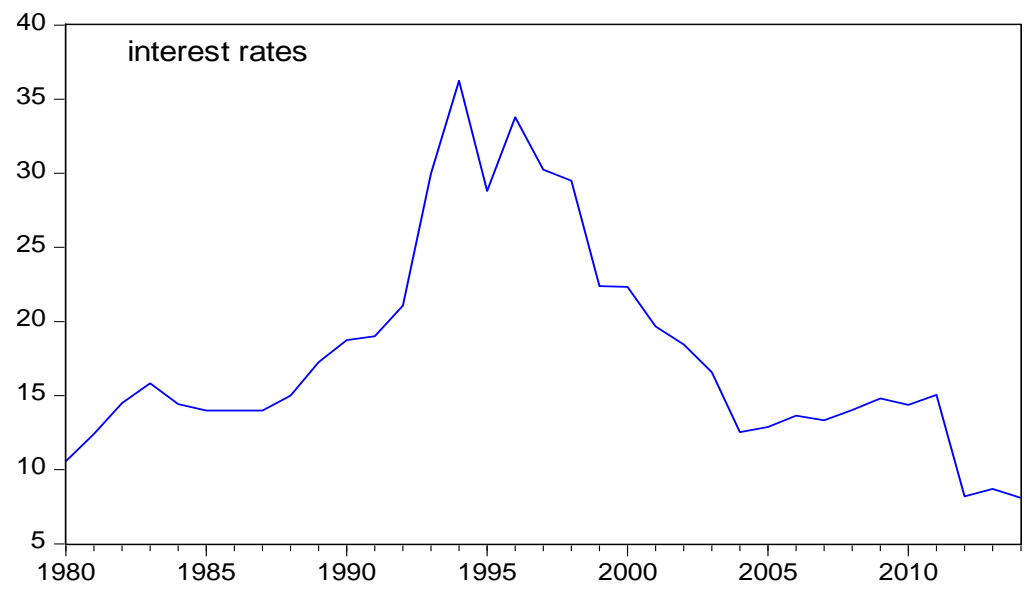


International Journal of Finance And Accounting

ISSNxxxx-xxxx (Paper)ISSN 2518-4113 (Online)

Vol.2, Issue 4, No.4 pp 58 - 83, 2017

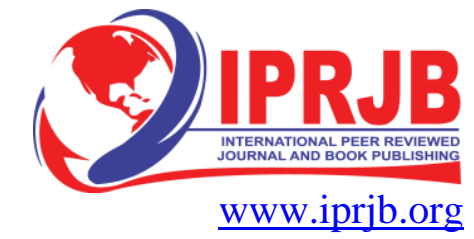

\section{Figure 5:Yearly Trend for Interest Rate}

\subsubsection{Trend Analysis for market capitalisation}

Figure 8 shows that market capitalisation have been increasing from 1991 to 1994 . The period between 1995 and 2001 experienced a decline in market capitalisation. This was the followed by sharp increase between 2002 and 2006. The figure below shows the trend analysis of market capitalisation of listed companies.

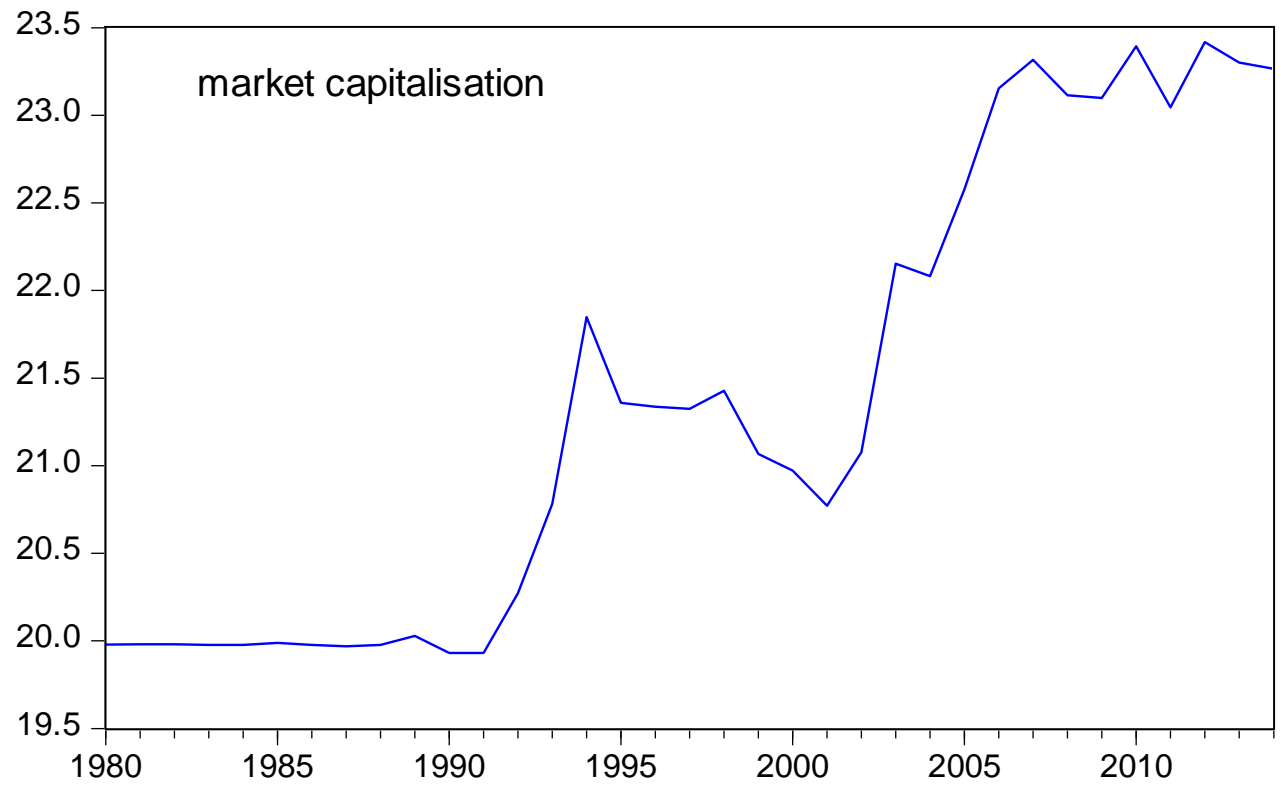

Figure 6: Yearly Trend for Market Capitalisation

\subsubsection{Trend Analysis for public debt and market capitalisation}

Figure 9 shows the variation of public debt against market capitalisation. The trend analysis establishes an inverse relationship between public debt and market capitalisation of list companies. There was a significant increase in market capitalisation in the period of 2000 and 2014. Public debt within period was exponentially reducing. The figure below shows the variation of public debt and market capitalisation in the period of between 1980 and 2014 


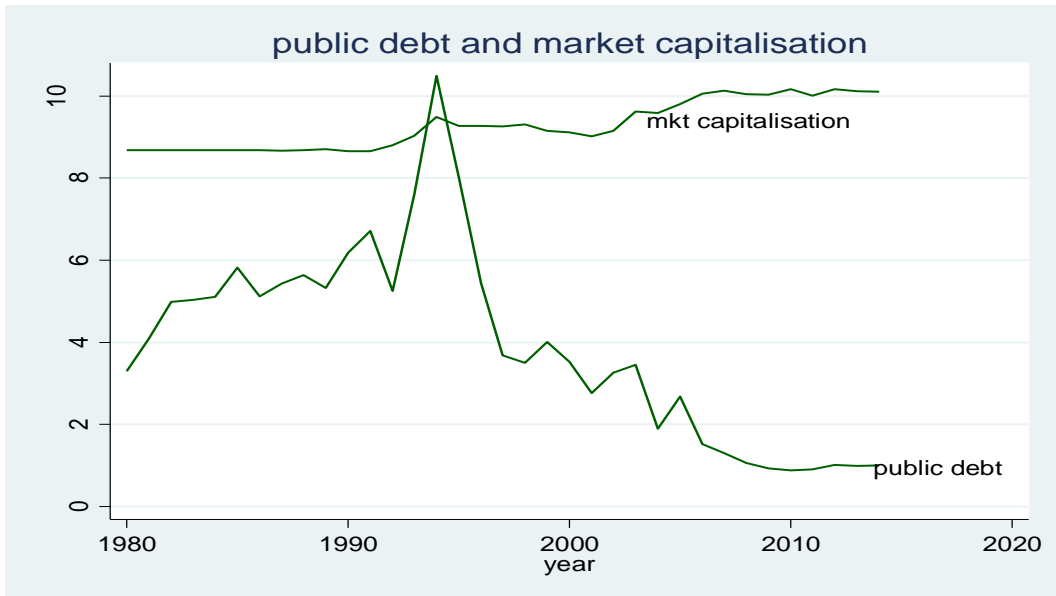

Figure 7: Yearly Trend for Public Debt and Market Capitalisation

\subsubsection{Trend Analysis for interest rates and market capitalisation}

Figure 8 shows the variation of interest rates against market capitalisation. The trend analysis establishes nonexistence of pronounce direct relationship between the two variables. For the period between 2012 and 2013 when interest rates were lowest market capitalisation hit its highest. The analysis also indicates that high interest rates do not affect market capitalisation but low interest rates increases market capitalisation by a small percentage. The figure below shows the variation of public debt and market capitalisation in the period of between 1980 and 2014

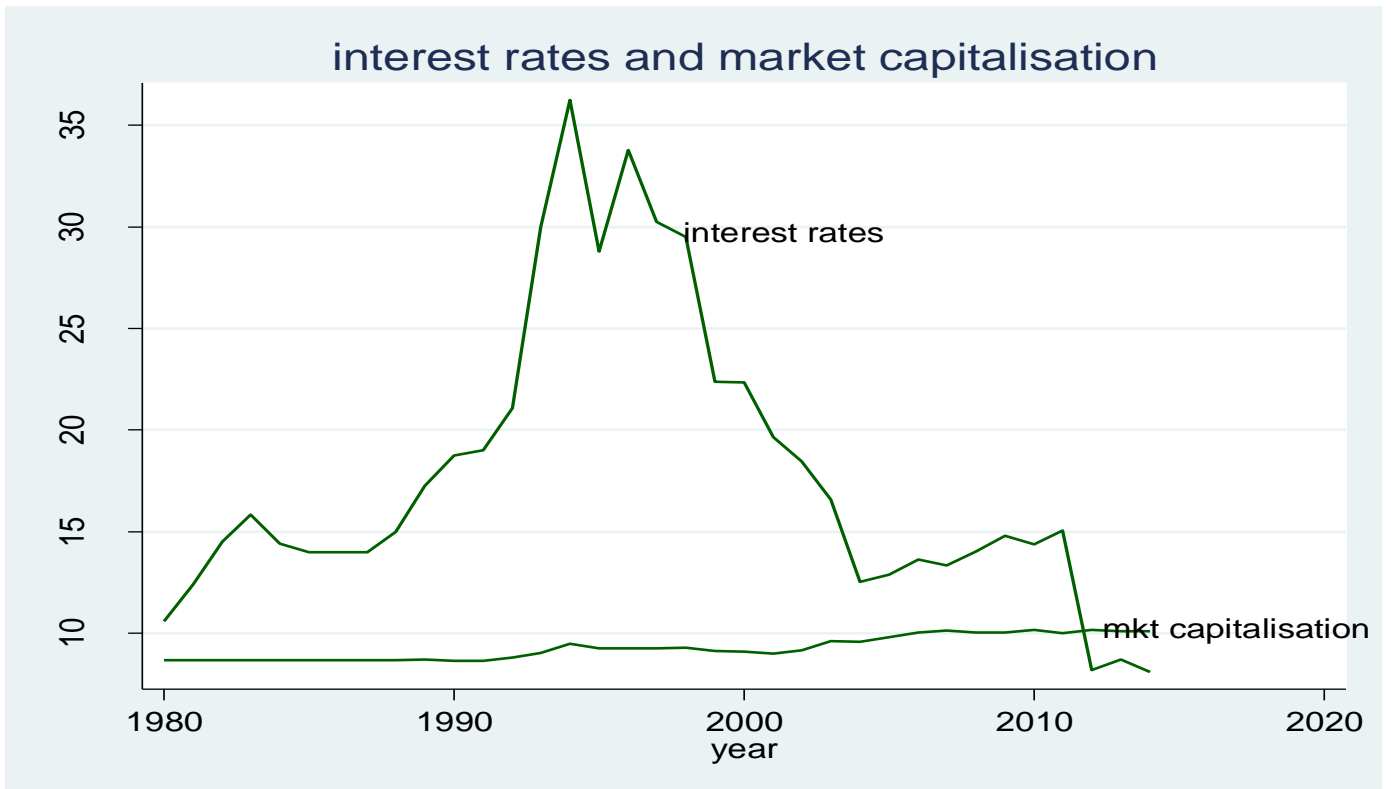




\section{Figure 8: Yearly Trend for Interest Rates and Market Capitalisation}

\subsubsection{Trend Analysis for inflation rates and market capitalisation}

Figure 9 shows the variation of inflation rates against market capitalisation. The trend analysis establishes that inflation rates of Kenya have been volatile between 1980 and 2014. Despite the volatility of inflation rates market capitalisation has maintained a steady increase within this period. The figure below shows the variation of public debt and market capitalisation in the period of between 1980 and 2014

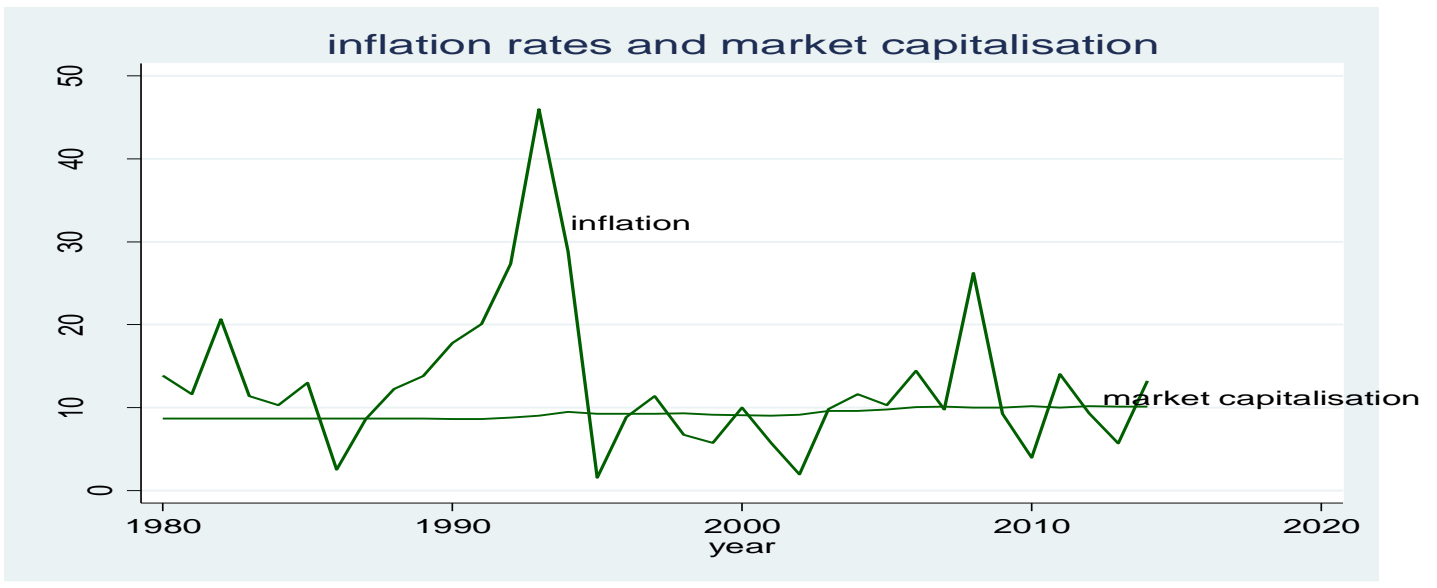

Figure 9: Yearly Trend for Inflation Rates and Market Capitalisation

\subsubsection{Trend Analysis for exchange rates and market capitalisation}

Figure 10 shows the variation of exchange rates against market capitalisation. The trend analysis establishes that increase in exchange rates does not necessarily impact or induce a corresponding change in market capitalisation. From the analysis it is possible to infer that factors other than exchange rates affect market capitalisation of list companies. Despite the volatility of exchange rates market capitalisation has maintained a steady increase within this period. The figure below shows the variation of public debt and market capitalisation in the period of between 1980 and 2014 


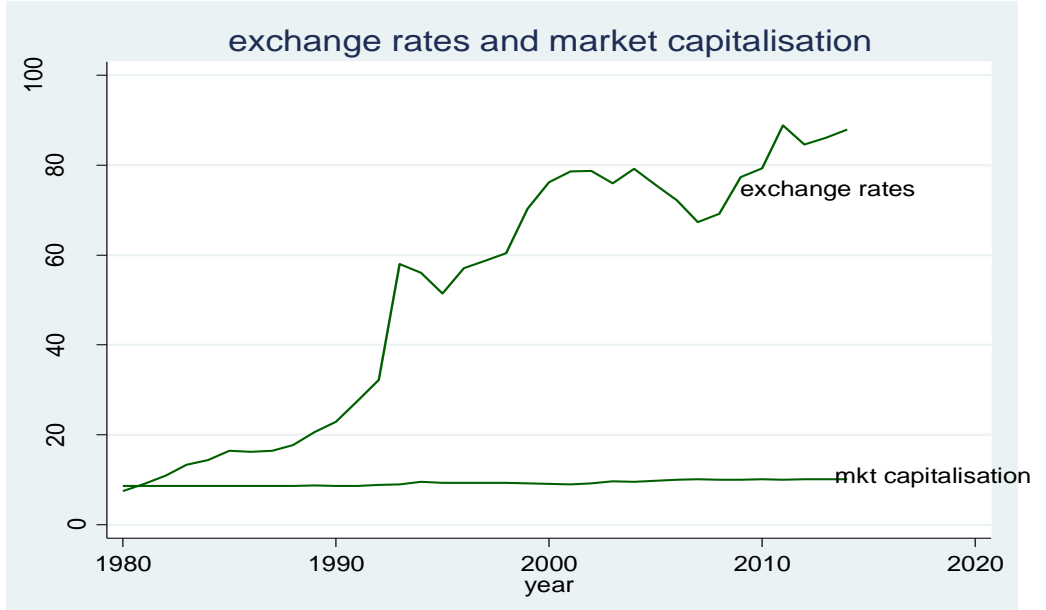

Figure 10: Yearly Trend for Exchange Rates and Market Capitalisation

\subsection{Pre-Estimation Tests}

Prior to running a regression model pre-estimation tests was conducted. The pre-estimation tests conducted in this case were the unit root tests and multicollinearity. This is usually performed to avoid spurious regression results from being obtained.

\subsubsection{Test for Multicollinearity}

According to William et al. (2013), multicollinearity refers to the presence of correlations between the predictor variables. In severe cases of perfect correlations between predictor variables, multicollinearity can imply that a unique least squares solution to a regression analysis cannot be computed (Field, 2009). Multicollinearity inflates the standard errors and confidence intervals leading to unstable estimates of the coefficients for individual predictors (Belsleyet al., 1980). Multicollinearity was assessed in this study using the variance inflation factors (VIF). According to Field (2009) VIF values in excess of 10 is an indication of the presence of Multicollinearity. The results in Table 4.3 present variance inflation factors results and were established to be less than 10 and thus according to Field (2009) indicates that there is no Multicollinearity.

Table 2: $\quad$ Variance Inflation Analysis test for Correlation.

\begin{tabular}{r|rr} 
Variable & VIF & I/VIF \\
\hline publicdebt & 4.53 & 0.220543 \\
interestra s & 2.79 & 0.357807 \\
exchangerate & 2.59 & 0.385638 \\
inflationr s & 1.18 & 0.849765 \\
\hline Mean VIF & 2.77 &
\end{tabular}




\subsubsection{Unit Root Tests}

Most economic variables are usually non-stationary in nature and prior to running a regression analysis. Unit root tests were thus conducted using the ADF test to establish whether the variables were stationary or non-stationary. The purpose of this is to avoid spurious regression results being obtained by using non-stationary series. Results in Table 4.3 indicated that all variables are non-stationary (i.e. presence of unit roots) at $1 \%, 5 \%$ and $10 \%$ levels of significance. This calls for first differencing of the non-stationary variables.

Table 3: $\quad$ Unit Root Tests at Level

\begin{tabular}{lcllll}
\hline Variable name & ADF test & $\begin{array}{l}\mathbf{1 \%} \\
\text { Level }\end{array}$ & $\begin{array}{l}\mathbf{5 \%} \\
\text { Level }\end{array}$ & $\begin{array}{l}\mathbf{1 0 \%} \\
\text { Level }\end{array}$ & Comment \\
\hline Exchange Rates & 1.65566 & -2.63473 & -1.951 & -1.61091 & $\begin{array}{l}\text { Stationary } \\
\text { Non } \\
\text { Inflation Rates }\end{array}$ \\
Interest Rate & -1.779 & -2.63473 & -1.951 & -1.61091 & $\begin{array}{l}\text { Stationary } \\
\text { Non }\end{array}$ \\
Public Debt & -0.5482 & -2.63473 & -1.951 & -1.61091 & $\begin{array}{l}\text { Stationary } \\
\text { Non } \\
\text { Market Capitalisation }\end{array}$ \\
\hline
\end{tabular}

Table 4 displays the unit root tests after first differencing. It is clear from the results in table 4 that all the variables become stationary (unit root disappears) on first differencing.

Table 4: $\quad$ Unit Root Tests at First Difference

\begin{tabular}{lrllll}
\hline Variable name & ADF test & $\begin{array}{l}\mathbf{1 \%} \\
\text { Level }\end{array}$ & $\begin{array}{l}\mathbf{5 \%} \\
\text { Level }\end{array}$ & $\begin{array}{l}\text { 10\% } \\
\text { Level }\end{array}$ & Comment \\
\hline D(Exchange Rate) & -4.72749 & -2.6369 & -1.95133 & -1.61075 & Stationary \\
D(Inflation Rate) & -6.43048 & -2.63921 & -1.95169 & -1.61058 & Stationary \\
D(Interest rate) & -5.73796 & -2.6369 & -1.95133 & -1.61075 & Stationary \\
D(public debt) & -5.25137 & -2.63921 & -1.95169 & -1.61058 & Stationary \\
D(market Capitalisation) & -5.09281 & -2.6369 & -1.95133 & -1.61075 & Stationary \\
\hline
\end{tabular}

\subsection{Post-Estimation Tests}

After running the specified regression model the test for normality, Heteroskedasticity and autocorrelation were conducted so as to ensure all the Ordinary Least Squares assumptions are not violated. A stationary error term implies that co integrated relationship among long run variables exist. In addition the presence of co integration indicates that there exists an underlying short run relationship. Such a short run relationship can be modelled through an error correction 
modelling approach. The purpose of an error correction modelling approach is to link the long run relationship to the short run relationship through an error term correction term.

\subsubsection{Test for normality}

The test for normality was examined using the graphical method approach as shown in the Figure 9 below. The results in the figure indicate that the residuals are normally distributed.
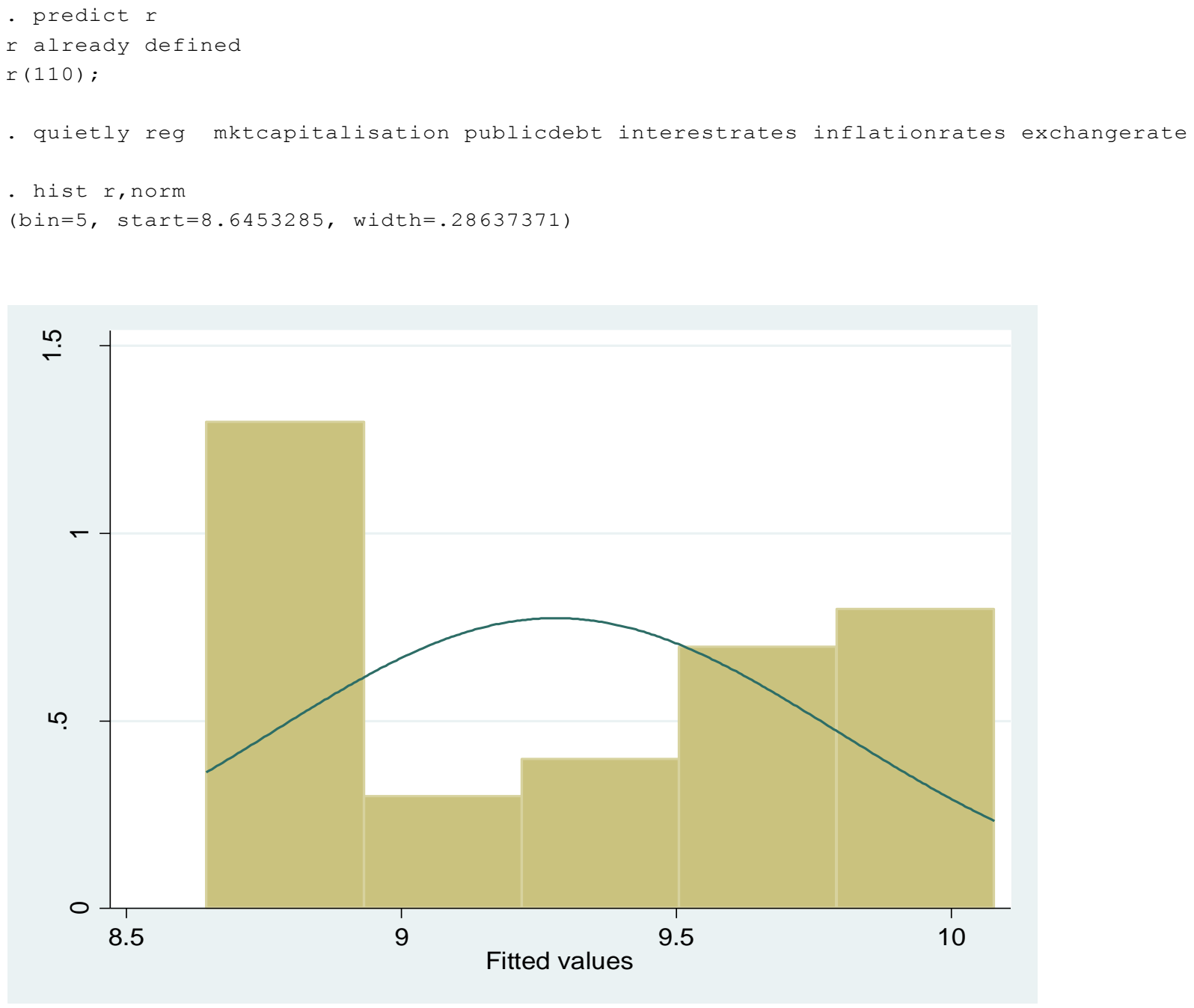

Figure 11: $\quad$ Histogram of Residuals

To further establish whether the residuals are normally distributed the study adopted the JarqueBera test which is a more conclusive test than the graphical inspection approach of testing for normality. The Table 4.5 below indicates the results of the Jarque-Bera test. The null hypothesis 
under this test is that the residuals are not significantly different from a normal distribution. Given that the p-value is greater than $5 \%$ for the residual, the null hypothesis is accepted and thus the conclusion that the residuals are normally distributed.

\section{Table 5:Jarque-Bera test/SK test for Normality}

. sktest $r$

\begin{tabular}{r|ccccc}
\multicolumn{9}{c}{ Skewness/Kurtosis tests for Normality } & & \\
Variable & Obs & $\operatorname{Pr}$ (Skewness) & Pr (Kurtosis) & adj chi2 (2) & Prob>chi2 \\
\hline$r$ & 35 & 0.8644 & 0.0000 & 23.66 & 0.0000
\end{tabular}

\subsubsection{Test for Heteroskedasticity}

Ordinary least squares (OLS) assumption stipulates that the residuals should have a constant variance (i.e. they should be Homoskedastic). Breusch-Pagan test was used to test for heteroskedasticity.

Table 4.6: Test for Heteroskedasticity

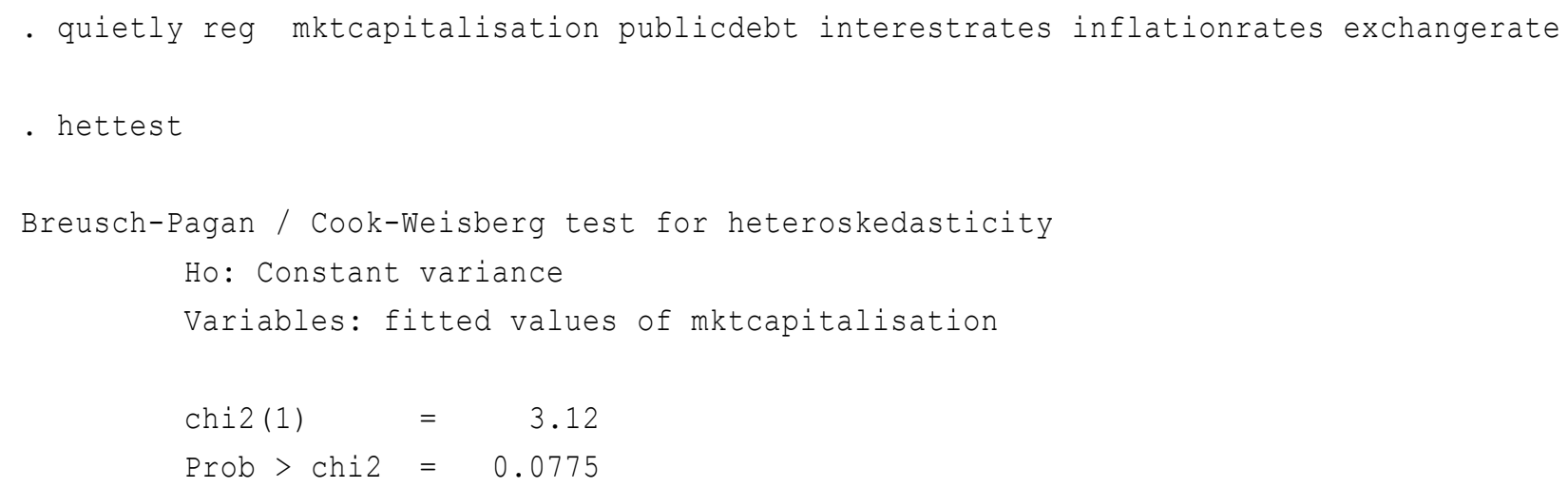

The results in the Table 4.6 below indicate that the error terms are Homoskedastic, given that the p-value is greater than the $5 \%$ and thus no violation of the OLS assumption of constant variance of residuals.

\subsubsection{Test for autocorrelation}

The test for autocorrelation was performed to establish whether residuals are correlated across time. OLS assumptions require that residuals should not be correlated across time and thus the Breusch-Godfrey test which is also an LM test was adopted in this study. The null hypothesis is that no first order serial /auto correlation exists. The results of the Table 4.7 below indicated that 
International Journal of Finance And Accounting

ISSNxxxx-xxxx (Paper)ISSN 2518-4113 (Online)

Vol.2, Issue 4, No.4 pp 58 - 83, 2017

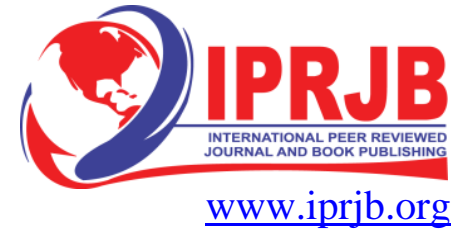

the null hypothesis of no autocorrelation is rejected and that residuals are not auto correlated (pvalue $=0.0001$ ).

Table 6: $\quad$ Serial Correlation Tests

- estat bgodfrey

Breusch-Godfrey LM test for autocorrelation

\begin{tabular}{c|ccc}
\hline $\operatorname{lags}(p)$ & $\operatorname{chi2}$ & df & Prob $>$ chi2 \\
\hline 1 & 15.765 & 1 & 0.0001 \\
\hline
\end{tabular}

HO: no serial correlation

\subsection{Correlation Analysis}

Table7: $\quad$ Correlation

- pwcorr mktcapitalisation exchangerate inflationrates interestrates publicdebt, star $(0.05)$

\begin{tabular}{|c|c|c|c|c|c|}
\hline & mktcap n & exchan e i & fflat s i & ntere s & ablic $\sim t$ \\
\hline mktcapital n & 1.0000 & & & & \\
\hline exchangerate & $0.8566 *$ & 1.0000 & & & \\
\hline inflationr s & -0.1229 & -0.1574 & 1.0000 & & \\
\hline interestra s & -0.2016 & 0.0296 & 0.2639 & 1.0000 & \\
\hline publicdebt & $-0.6850 *$ & $-0.5882 *$ & $0.3784 *$ & $0.6301 *$ & 1.0000 \\
\hline
\end{tabular}

\subsection{Regression Results on the Determinants of market Capitalisation}

The regression results in the table show that exchange rates are positively and significantly related to market capitalisation. This implies that when exchange rates increase there will be a corresponding increase in market capitalisation and vice versa. This is consistent with the results of Kigume (2011) who also found that there existed a positive relationship between exchange rates and market capitalisation in Kenya.

Further the results show that inflation rates are positively rated to market capitalisation. The relationship however does not significantly affect market capitalisation. These findings are consistent with those of Olubusoye and Oyaromade (2008) who also found that lagged inflation and petroleum prices propagate the dynamics of inflationary process in Nigeria. 
The study also established that the interest rates have a negative and significant relationship with market capitalisation. This implies that high interest rates translated to reduction in market capitalisation of listed companies in the period between 1980 and 2014. These results are consistent with those of Akbari and Rankaduwa (2006) who also established that the, interest rates positively and significantly affect market capitalisation.

Table 8: $\quad$ Regression Results on the Determinants of Inflation

- reg mktcapitalisation exchangerate inflationrates interestrates publicdebt

\begin{tabular}{|c|c|c|c|c|c|c|c|}
\hline Source & S S & $d f$ & MS & Number of & obs & $=$ & 35 \\
\hline Model & 9.02775365 & 4 & 2.25693841 & Prob $>F$ & & $=$ & 0.0000 \\
\hline Residual & 2.26274857 & 30 & .075424952 & R-squared & & $=$ & 0.7996 \\
\hline Total & 11.2905022 & 34 & .332073595 & $\begin{array}{l}\text { Adj R-squa } \\
\text { Root MSE }\end{array}$ & red & $\begin{array}{l}= \\
=\end{array}$ & $\begin{array}{l}0.7729 \\
.27464\end{array}$ \\
\hline
\end{tabular}

\begin{tabular}{lcccccc}
\hline $\begin{array}{l}\text { Market } \\
\text { capitalization }\end{array}$ & Coef. & Std. Err. & $\mathrm{t}$ & $\mathrm{P}>\mathrm{t}$ & \multicolumn{2}{l}{$\begin{array}{l}\text { Conf. } \\
\text { Conf }\end{array}$} \\
\hline Exchange rate & 0.015348 & 0.002651 & 5.79 & 0 & 0.009934 & 0.020763 \\
Inflation rates & 0.0069 & 0.005828 & 1.18 & 0.246 & -0.005 & 0.018802 \\
Interest rates & -0.01025 & 0.010893 & -0.94 & 0.0034 & -0.0325 & 0.011994 \\
Public debt & -0.04782 & 0.042569 & -1.12 & 0.027 & -0.13476 & 0.039116 \\
cons & 8.767254 & 0.190148 & 46.11 & 0 & 8.378921 & 9.155587 \\
\hline
\end{tabular}

\section{0: SUMMARY, CONCLUSIONS AND RECOMMENDATIONS}

\subsection{Summary of Findings}

\subsubsection{Macroeconomic variables effects on market capitalisation in Kenya}

The main objective of the study was to determine the effects of macroeconomic variables in Kenya. The results revealed that exchange rates, interest rates and public debt have a significant effect on market capitalisation in Kenya. These study findings are inconsistent with the study of Ndun'gu (1996) who found that public debt, exchange rate changes and interest rate changes all have significant effects on the market capitalisation.

\subsubsection{Public Debt Effect on Market Capitalisation}

The first objective of the study is to establish the effect of public debt on market capitalisation of listed companies. The study findings show that public debt has a negative and significant 
relationship with market capitalisation of listed companies in the period between 1980 and 2014. These results are consistent with those of Misati\&Nyamongo (2008) who also established that the, public debt positively and significantly affect market capitalisation. This study finding is also consistent with the study of Olubusoye and Oyaromade (2008) that analyzed the effect of public debt in Nigeria and found out that public debt was among the factors that significantly affect the market capitalisation in Nigeria.

\subsubsection{Exchange Rates Effect on Market Capitalisation}

The second objective of the study is to establish the effect of exchange rate on market capitalisation of listed companies. The study findings indicate exchange rates are positively and significantly related to market capitalisation. This is consistent with the results of Kigume (2011) who also found that there existed a positive relationship between exchange rates and market capitalisation in Kenya. The study findings indicate exchange rates are positively and significantly related to market capitalisation. This is consistent with the results of Kigume (2011) who also found that there existed a positive relationship between exchange rates and market capitalisation in Kenya.

\subsubsection{Inflation Rates Effect on Market Capitalisation}

The third objective of the study is to establish the effect of inflation rate on market capitalisation of listed companies. The results show that inflation rates are positively rated to market capitalisation. The relationship however does not significantly affect market capitalisation. inflation and petroleum prices propagate the dynamics of inflationary but not market capitalisation in NigeriaThese findings are consistent with those of Olubusoye and Oyaromade (2008) who also found that.

\subsubsection{Interest Rates Effect on Market Capitalisation}

The final objective of the study is to establish the effect of interest rate on market capitalisation of listed companies. The study also established that the interest rates have a negative and significant relationship with market capitalisation in the period between 1980 and 2014. These results are consistent with those of Akbari and Rankaduwa (2006) who also established that the, interest rates positively and significantly affect market capitalisation in Kenya.

in the literature review of the

\section{2: Conclusions}

\subsubsection{Public Debt Effect on Market Capitalisation in Kenya}

Based on the findings above the study concluded that public debt affect market capitalisation in Kenya. From these findings, the study can therefore assert that there is a significant relationship between public debt and market capitalisation of listed companies in Kenya. 


\subsubsection{Exchange Rates Effect on Market Capitalisation in Kenya}

Based on the findings above the study concluded that exchange rates affect market capitalisation in Kenya. From these findings, the study can therefore assert that there is a significant relationship between public debt and market capitalisation of listed companies in Kenya.

\subsubsection{Inflation Rates Effect on Market Capitalisation in Kenya}

Based on the findings above the study concluded that Kenyan inflation model exhibits a linear structure. Most inflation models estimated usually adopt a linear approach and thus this study obtained similar results. The study findings also show no significance relationship between inflation and market capitalisation of listed companies.

\subsubsection{Interest Rates Effect on Market Capitalisation}

The study also established the existence of a negative but significant relationship between interest rates and of listed companies in Kenya. These findings are in line with the findings of previous studies highlighted market capitalisation study.

\section{$5.3 \quad$ Recommendations}

Several policy implications emanate from the study. The study recommends that policy makers should adopt the findings of this study. According to the results, exchange rates, public debt and interest rates were the significant determinant of market capitalisation of listed companies in Kenya during the study period. Macroeconomic variables should be factored when formulating policies on market capitalisation.

This study recommended that, since the Kenyan stock market is not really exposed to the negative effects of currency volatility, government can use exchange rate as a policy tool to attract foreign portfolio investment.

\subsection{Limitations of the study}

This study used few variables that are public debt, interest rates, exchange rate and inflation rates. The study left out variables like, Expansion of the Private Sector, Increasing Public Expenditures, Industrial Disputes, Natural Calamities Artificial Scarcities and Global factors which might have affected market capitalisation in Kenya during the study period.

This study used data from secondary sources only which were not exhaustive. The study could have also included primary data collection from households and organizations on what they think on what determine market capitalisation in Kenya. This study faced challenges of data availability and reliability due to inconsistency of data from various data sources and there is therefore the need for the government to synchronize all these data sources that emanate from the country. 


\section{REFERENCES}

Abdulland, S.J. (1997) Stock Returns and Volatility: an Empirical Study of the U.K Stock Market, Journal of Banking and Finance, 16, pp. 37-59.

Adam, S., Dasgupta, S. and Glen, J. (2008) Return behaviour in emerging stock markets, World Bank Economic Review, 9, pp. 131-152.

Adejimi, A., Oyediran, O. S., \&Ogunsanmi, E. B. (2010). Employing Qualitatively Enriched Semi Structured Questionnaire in Evaluating ICT Impact on Nigerian 'Construction Chain Integration'. The Built \& Human Environment Review, 3(1), 49-62.

Ambunya, P. L. (2012). The relationship between exchange rate movement and stock market returns volatility at the Nairobi Securities Exchange (Doctoral dissertation).

Asperm, K. (1989), "Macroeconomic Variables, Firm Characteristics and Stock Returns: Evidence from Turkey", International Research Journal of Finance and Economics, $\quad$ 16, pp. 35-45.

Booth.J. (1997), "Macro variables and international stock return predictability", International Journal of Forecasting, 21, pp. 137-166.

Brown, B.A (1990), "Empirical Relationship between Macro-economic Volatility and Stock Returns: Evidence from Latin American markets", International Review of Financial Analysis, 17, pp. 396-410. 
International Journal of Finance And Accounting

ISSNxxxx-xxxx (Paper)ISSN 2518-4113 (Online)

Vol.2, Issue 4, No.4 pp 58 - 83, 2017

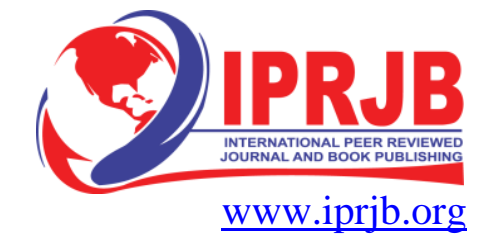

Burns, A. \& Groove, B. (2003); The Practice of Nursing Research: Conduct, critique \& utilization. 4th edition. W. B. Saunders Company

Chan, M. (2003) Volatility Interactions between Stock Returns and Macroeconomic Variables Malaysian Evidence, Savings and Development, 26 (2), pp. 483-194.

Chen, N., Roll, R. and Ross, S.A., (1986), "Economic Forces and the Stock Market”, Journal of Business, Vol. 59, pp. 383-403.

Demirgüç-Kunt, A., \& Levine, R. (1996). Stock markets, corporate finance, and economic growth: an overview. The World Bank Economic Review, 223-239.

Dimitrova D. (2005). The Relationship between Exchange Rates and Stock Prices: Studied in a Multivariate Model. Issues in Political Economy 14.

Fannery M.J. and Protopapadakis A.A., (2002), "Macroeconomic Factors Do Influence Aggregate Stock Returns", The Review of Financial Studies, Vol. 15, pp. 751-782.

Gaske, R. (1983). The fiscal and Monetory linkage between stock return and inflation. journal of finance, 38,7-33.

Geetha, D.E, Wohar, M.E \&Rangvid. J. (2011), "Macro variables and international stock return redictability”, International Journal of Forecasting, 21, pp. 137-166. 
International Journal of Finance And Accounting

ISSNxxxx-xxxx (Paper)ISSN 2518-4113 (Online)

Vol.2, Issue 4, No.4 pp 58 - 83, 2017

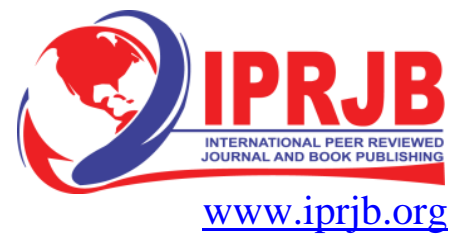

Habibullah, M.S. and A.Z. Baharumshah. (2000). Testing for Informational Efficient Market Hypothesis: The Case for Malaysian Stock Market. In M.S. Habibullah and A.Z. aharumshah (eds.), Issues on Monetary and Financial Economics: Studies on Malaysian Economy.

Hondroyiannis, G., and Papapetrou E. (2001).Macroeconomic Influence on the Stock Market.Journal of Economics and Finance 25, 33-49.

Ibrahim, M. H., and Aziz, H. (2003). Macroeconomic Variables and the Malaysian Equity Market: A View through Rolling Subsamples. Journal of Economic Studies 30, 6-27.

Kiptui, M. (2009, May).Oil Price Pass-Through into Inflation in Kenya.In African Econometric Society (AES) Conference Proceedings.

Kothari, C. R. (2004). Research Methodology, 2nd edition. New Delhi: New Age International (P) Ltd.

Leroy, S. and Porter, R., (1981), "The present value relation: Tests based on implied variance bonds", Econometrica, Vol. 49, pp. 555-574.

Levine, R. (1999). Law, finance, and economic growth.Journal of financial intermediation, 8(1), 8-35.

McCauley, R. N. (2003). Unifying government bond markets in East Asia.BIS Quarterly Review, December. 
International Journal of Finance And Accounting

ISSNxxxx-Xxxx (Paper)ISSN 2518-4113 (Online)

Vol.2, Issue 4, No.4 pp 58 - 83, 2017

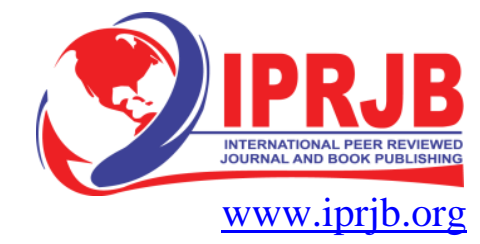

Mlambo, C., Maredza, A., \&Sibanda, K. (2013). Effects of Exchange Rate Volatility on the Stock Market: A Case Study of South Africa. Mediterranean Journal of Social Sciences, 4(14), 561.

Mokerjee, Rajen and Qiao Yu, (1997), "Macroeconomic Variables and Stock Prices in a Small Open Economy: The Case of Singapore”, Pacific-Basin Finance Journal, Vol. 5, pp. 377-388.

Mugenda. O \& Abel G, Mugenda, (2003), "Research Methods Quantities and Qualitative Approaches”, Nairobi, Acts Press Publishers.

Mukherjee, Tarun K. and Atsuyuki Naka (1995), “Dynamic Relation Between macroeconomic Variables and the Japanese Stock Market: An Application of a Vector Error Correction Model", Journal of Financial Research, Vol.18, pp. 223-237.

Muriuki, T. G. (2013). The Effect of foreign exchange rate fluctuation on the financial performance of listed companies in Kenya (Doctoral dissertation).

Naka, M. (1994). Macroeconomic Variables and the Malaysian Equity Market: A View through Rolling Subsamples. Journal of Economic Studies 30, 6-27.

Naka, Mukherjee and Tufte (2001).Microeconomic Variables and Performance of the Indian Stock Market. University of New Orleans, USA.

Nguyen, P. (2007), “Macroeconomic factors and Japan's industry risk”, Journal of ～Multinational Financial Management”, 17, pp. 173-185. 
International Journal of Finance And Accounting

ISSNxxxx-Xxxx (Paper)ISSN 2518-4113 (Online)

Vol.2, Issue 4, No.4 pp 58 - 83, 2017

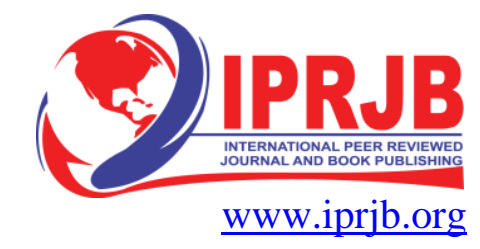

Nishat, E. and Shaheen, M. (2004) Macroeconomic Volatility and Stock Market Volatility: Empirical Evidence on Finnish Data, Applied Financial Economics, 7, pp. 419-426.

Nyamongo M.E. \&Misati R. (2010), "Modelling the time-varying volatility of equities returns in Kenya", African Journal of Economic and Management Studies", 1 (2), $\quad$ pp.183 - 196.

Olweny, T.O. and Kimani, D. (2011).Stock market performance and economic growth Empirical Evidence from Kenya using Causality Test Approach.Advances in management \& Applied Economics, vol.1, no.3, 2011, 153-196.International Scientific Press.

Omole, D. A., \&Falokun, G. O. (1999). The impact of interest rate liberalization on the corporate financing strategies of quoted companies in Nigeria. AERC.

Pan, N. F., Roll, R. and Ross, S. (2007) Economics forces and the stock market, Journal of Business, 59 (3), pp. 383-403.

Patro, D.K., Wald, J.K. and Wu, Y., (2002), "The Impact of Macroeconomic and Financial Variables on Market Risk: Evidence from International Equity Returns", European Financial Management, Vol. 8, pp. 421-447.

Shiller, V. (1981), Emerging markets: a new opportunity for improving global portfolio performance, Financial Analysis Journal, 39, pp. 51-58.

Sims, H.(1986), " Does the stock market rationally reflect fundamental values? ", Journal o $f$ Finance. 41, pp. 591-601. 
Singh, A. (1997). Financial liberalisation, stockmarkets and economic development*.The Economic Journal, 107(442), 771-782.

Summers, L. H. (2000). International financial crises: causes, prevention, and cures. American Economic Review, 1-16.

Tirole, J. (1991). Privatization in Eastern Europe: incentives and the economics of transition. In NBER Macroeconomics Annual 1991, Volume 6 (pp. 221-268). MIT Press.

Toda, L. and Yamamoto, R. (1995). The Interrelationship between Macroeconomic Variables and Stock Prices: the Case of Japan. Journal of Asia-Pacific Business 3.

Upagade, V. \&Shende, A. (2012).Research Methodology. S. Chand\& Company Ltd. New Delhi ,India

Wiersman, R. (1995). Surveys.In T. Greenfield (Ed.), Research methods.Guidance for $\quad$ postgraduates. London: Arnold

Yu Hsing, (2011), "The Stock Market and Macroeconomic Variables in a BRICS Country

and Policy Implications", International Journal of Economics and Financial Issues, 1(1), pp. 1218.

Holbrook, M. C., \& Koenig, A. J. (Eds)(2000). Foundations of education: Instructional strategies for teaching children and youths with visual impairment. New York: American foundation of the Blind Press. 
Hoy, W. K. \&Miskel, C. G. (1982). Education administration: Theory, research and practice (2nd Ed.). New York: Random House, Inc.

Jefkins, F. (1998). Public relations(5th Ed). Great Britain: Pearson Professional Ltd.

Jensen-marrie, T. (2003.Frameworks for tanscribing and analyzing discourse of the

classroom. Retrieved July 232009 from

http://www.aare.edu.au/03pap/jen03641.pdf.

Katz, D., \& Kahn, R. L. (1978).The social psychology of organizations (2 ${ }^{\text {nd }}$ Ed.). New York: John Wiley \& sons, Inc.

Pankake, A. M., \& Palmer, B. (1996).Making the connections: linking staff development interventions to implementation of full inclusion. Journal of StaffDevelopment, 17(3), 2630 .

Patel, S. (1989).Communication revolution: A study of video penetration in India. New Delhi: India space research organization. Portland Oregon. Retrieved August 10, 2010 from http:// www.nwrel.org/request.

Patton, M. Q. (2002). Qualitative research and evaluation methods ( ${ }^{\text {rd }}$ Ed.). Thousand Oaks, California: Sage Publications, Inc.

Pawlas, A. M. (1989). Making schools more responsive to at-risk students. New York: Urban Education Publishers.

Pawlas, A. M., \&Pawlas, G. (2005).The administrator's guide to school-community relations. Larchmont, New York: Eye on Education, Inc.

Perrigo, E. M., \&Graut, D. (1982). Is academia in "sync" with the business world? Journal of career planning and employment,54(3), 58-60. 
International Journal of Finance And Accounting

ISSNxxxx-xxxx (Paper)ISSN 2518-4113 (Online)

Vol.2, Issue 4, No.4 pp 58 - 83, 2017

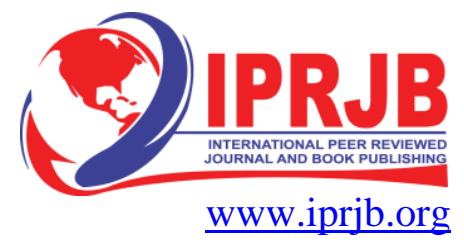

Pearsons, H. G., \&Tompskin, M. A. (1997).Cognitive-behavioural case formulation.

New York: Guilford Press.

Peterson, B. (2004). Bluesreak inside setblue: The upstart that rocked an industry. New York: Portfolio.

Punch, K. (2001). Introduction to social research: Qualitative and quantitative approaches. London: Sage Publication Ltd.

Quinn, D. (2004). Internal Communication Audit: A case study. An International Journal, 9(2), 146-158. $\quad$ Retrieved October 2009 from http://www.emeraldinsight.com/journals.htm?articleid=858093\&show=abstract.

Ravi-prakash, T.(2004). Advanced educational administration. New Delhi: Kanishka Publishers

Robbins, S. P., \& Judge, T. A. (2007).Organizational behavior (12th Ed.). Europe: Pearson Education, Inc.

Robbins, S. P., Judge, T. A., Ondendaal, A., \&Roodt, G. (2009).Organization behaviour: Global and southern African perspectives ( $2^{\text {nd }}$ Ed.). Pinelands, Cape Town: Pearson Education (Pty) Limited.

Rogers, E. M., \&Aggrawala-Rogers, R. (1976).Communication in organizations. New York: Frees Press.

Samovar, L.A., Porter, R. E., \&McDaniel,E. R. (2011). Intercultural communication: A reader (13 Ed.). Boston, Massachusetts:WadsworthCengage Learning.

Sanacore, J. (1997). Reaching out to a diversity of learners: Innovative educators need substantial support.Journal of Adolescentand Adult Literacy, 41, 224-229.

Sharma, B. (1997). Theory of educational administration. New Delhi: Commonwealth Publishers. 
International Journal of Finance And Accounting

ISSNxxxx-xxxx (Paper)ISSN 2518-4113 (Online)

Vol.2, Issue 4, No.4 pp 58 - 83, 2017

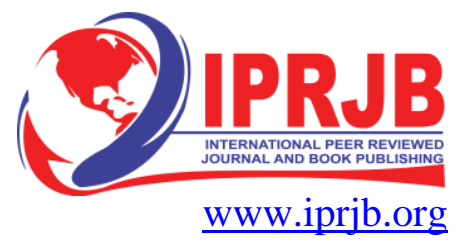

Sharma, Y. K. (2008).Comparative education: A comparative study of educational systems. New Delhi: Kanishka Publishers.

Smith, K. D. (1992). Creating understanding: Handwork for Christian communication. New York: Zondervan Publishing House.

Smith, L., \&Mounter, P. (2005).Effective internal communication. Great Britain: Kogan Page.

Smith, L., \&Mounter, P. (2008).Effective communication (3rd Ed.). New York: Prentice Hall Publishing Company.

Stacks, D. W. (Ed.).(2006). Dictionary of public relations measurement and research.Retrieved August 10, 2010 from http://www.instituteforpr.

Steinberg, S. (1995). Introduction to communication: The basic. South Africa: Juta\& Company Limited.

Stern, G. M. (1994). 15 Ways internal auditing departments are adding value. Internal Auditor, $51(2), 30-33$.

Talaska, F., Fischbach, M., \& Barnett, D. (2008).Importance of communication. New York: Dogles University.

Tashakkori, A., \&Teddie, C. (Eds).(2003). Handbook of mixed methods in social and behavioural research.London: Sage Publications Inc.

The Kamunge Report. (1988). The report of presidential working party for education andmanpower training for the next decade and beyond. Nairobi: Government Printer.

The Laws of Kenya. (1980). The Education Act, Chapter 211. Nairobi, Kenya: Government Printers. 